\title{
A study of the pattern of admissions and outcome in a neonatal intensive care unit at high altitude
}

\author{
Raghvendra Narayan ${ }^{1}$ \\ Sri Lanka Journal of Child Health, 2012: 41(2): 79-81
}

\begin{abstract}
Objective: To document the number, disease pattern and outcome of patients admitted to a neonatal intensive care unit (NICU) at a high altitude having catchment areas of patients at about the same level.

Design: Descriptive study

Method: The study was conducted at a level II Care NICU at Sikkim Manipal Institute of Medical Sciences at Gangtok from November 2004 to October 2005. The data of all the admitted neonates were analyzed for age, weight at the time of admission, sex, cause of admission and outcome.
\end{abstract}

Results: 212 neonates (58\% males) were admitted during the study period. $17.5 \%$ were admitted within 6 hours of birth and $51.4 \%$ within 72 hours of birth. Neonatal jaundice, prematurity, infections and birth asphyxia were the major causes of admission. NICU mortality was $8 \%$. The most common cause of death was prematurity followed by birth asphyxia.

Conclusions: Study showed relatively increased incidence of neonatal jaundice and decreased neonatal infections at high altitude.

(Key words: neonatal jaundice; birth asphyxia; high altitude)

\section{Background}

Nearly 26 million babies are born in India each year accounting for $20 \%$ of global births. Of these, 1.2 million die before completing the first four weeks of life. This accounts for nearly $30 \%$ of the total 3.9 million neonatal deaths worldwide. Among neonatal deaths mortality is highest in the first seven days.

${ }^{1}$ Associate Professor, Department of Paediatrics, Maharishi Markandeshwar Institute of Medical Sciences and Research, Mullana, Haryana, India

(Received on 21 August 2011: Accepted after revision on 28 October 2011)
Knowing the disease pattern in the neonatal intensive care unit (NICU) and disease-wise mortality rate we can use our available resources best and can make requisite efforts to reduce morbidity and mortality. This study intends to see the relative incidence of neonatal diseases and their outcomes at high altitude as the study centre Sikkim Manipal Institute of Medical Sciences, Gangtok is located at around 1600 metres above sea level and having a catchment area of patients about the same level.

\section{Objective}

This study aims to see the pattern of admissions and outcomes in NICU located at high altitude having a catchment area of patients at about the same level.

\section{Method}

Data of all babies admitted to NICU from November 2004 to October 2005 was recorded and analysed for age, weight, sex, indication for admission, and final outcome with their referral sources. The location where the study was conducted is a level II care NICU having facilities of resuscitation unit, phototherapy unit, radiant warmer, open and closed incubator facilities and also neonatal ventilator. All the sick babies, both born within the hospital and outside, were included in the study except those of neonatal tetanus cases because there was a separate ward for them. Surgical cases were admitted for stabilization and further referred to higher centre. All the diagnoses were made by standard criteria.

\section{Results}

The total number of babies admitted to NICU was 212. Among them 58\% were male and $42 \%$ female. Of the 212, $18 \%$ were admitted within 6 hours of birth and $52 \%$ within 72 hours. Causes of admissions to NICU are shown in table 1. 
Table 1

Causes of admissions to NICU

\begin{tabular}{|c|c|}
\hline Cases diagnosed & No. of cases $(\%)$ \\
\hline $\begin{array}{ll}\text { Neonatal jaundice } \\
\text { - } & \text { Exaggerated } \\
\text { - } & \text { physiological jaundice* } \\
\text { - } & \text { Hereast milk jaundice } \\
\text { - } & \text { Neonatal hepatitis }\end{array}$ & $\begin{array}{l}115(54) \\
101(48) \\
08(04) \\
03(01) \\
03(01)\end{array}$ \\
\hline Prematurity & $27(13)$ \\
\hline Birth asphyxia & $25(12)$ \\
\hline Neonatal infections & $13(06)$ \\
\hline $\begin{array}{l}\text { Meconium aspiration } \\
\text { syndrome (MAS) }\end{array}$ & $09(04)$ \\
\hline $\begin{array}{l}\text { Respiratory distress } \\
\text { syndrome (RDS) }\end{array}$ & $11(05)$ \\
\hline Hypoglycaemia & $05(02)$ \\
\hline $\begin{array}{l}\text { Multiple congenital } \\
\text { malformations }\end{array}$ & $01(0.5)$ \\
\hline Hypothermia & $01(0.5)$ \\
\hline $\begin{array}{l}\text { Intrauterine growth } \\
\text { retardation }\end{array}$ & $01(0.5)$ \\
\hline $\begin{array}{l}\text { Surgical conditions } \\
\text { - } \quad \text { Imperforate anus } \\
\text { - } \quad \text { Congenital megacolon } \\
\text { - } \quad \text { Duodenal atresia }\end{array}$ & $\begin{array}{c}02(01) \\
01(0.5) \\
01(0.5)\end{array}$ \\
\hline
\end{tabular}

*Physiological jaundice with bilirubin levels

$>12 \mathrm{mg} /$ dl in term \& $>15 \mathrm{mg} /$ dl in preterm babies

Overall NICU mortality rate was $8 \%$ (17 deaths among 212 admissions). The distribution of deaths according to disorders is shown in table 2 .

Table 2

Distribution of deaths in NICU

\begin{tabular}{|l|c|}
\hline \multicolumn{1}{|c|}{ Disorder } & No. of deaths (\%) \\
\hline Prematurity & $07(41)$ \\
\hline Birth asphyxia & $04(24)$ \\
\hline $\begin{array}{l}\text { Multiple congenital } \\
\text { anomalies }\end{array}$ & $02(12)$ \\
\hline Neonatal septicaemia & $01(06)$ \\
\hline RDS & $01(06)$ \\
\hline MAS & $01(06)$ \\
\hline MAS + birth asphyxia & $01(06)$ \\
\hline
\end{tabular}

\section{Discussion}

Data obtained from the present study shows that the maximum number of cases (48\%) admitted were of neonatal jaundice followed by prematurity, birth asphyxia, neonatal infections and others. High altitude leading to increased red blood cell mass may be the reason for the increased number of cases of neonatal jaundice. This is further suggested by the study of .Leibson $\mathrm{C}$ et $\mathrm{al}^{3}$ in which they found that on the $3^{\text {rd }}$ day after birth the haematocrit levels of babies were above normal. Very few cases of neonatal jaundice were of the pathological type. Other common causes of admissions were prematurity $(13 \%)$, birth asphyxia (12\%), neonatal infections $(6 \%)$ and meconium aspiration syndrome (4\%). There were less numbers of cases of neonatal infections in comparison to results from studies done in plain area ${ }^{1-2}$. In this study the overall mortality was $8 \%$ which was satisfactory in comparison to reports of other studies such as Garg P et al $(35 \%)^{1}$ and Parkash $\mathrm{J}$ et al $(25 \%)^{2}$. The most common cause of death was prematurity followed by birth asphyxia. This is in accordance with the Indian national figures where prematurity and birth asphyxia are the leading causes of death. Early recognition of neonatal jaundice and immediate intervention led to few complications and sequelae. A thorough examination of baby just after birth for early recognition and timely referral of surgical conditions led to better outcomes.

\section{Conclusions}

The present study shows that there are relatively greater numbers of admissions of neonatal jaundice and lesser numbers of neonatal infection cases at high altitude compared to studies done in plain areas ${ }^{1-2}$. Increased incidence of jaundice may be due to increased red cell mass of neonates at high altitude but this needs further studies ${ }^{3-4}$.This study identifies early neonatal period as the major contributor to neonatal mortality. With prematurity being the commonest cause of death, attempts to prolong the pregnancy might improve the neonatal outcome considerably.

\section{References}

1. Garg P, Krishak R, Shukla DK. NICU in a community level hospital. Indian J Pediatr 2005; 72(1): 27-30. http://dx.doi.org/10.1007/BF02760575

2. Parkash J, Das N. Pattern of admissions to neonatal unit. J Coll Physicians Surg Pak 2005; 15(6):341-4.

3. Leibson $\mathrm{C}$, Brown $\mathrm{M}$ et al. Neonatal hyperbilirubinemia at high altitude. $A m J$ Dis Child 1989; 143(8):983-7. 
4. Ballew C, Hass JD. Haematologic evidence of fetal hypoxia among newborn infants at high altitude in Bolivia. Am J Obstet Gynec 1986; 155(1):166-9.

5. L Bahl, Rakesh S. et al. Etiology of neonatal jaundice at Shimla. Indian Pediatrics1994; 31(10):1275-8.

6. Samuel N Obi, Benson N Onyire. Pattern of neonatal admission and outcome at a Nigerian tertiary health institution. Orient $J$ Medicine 2004; 16(3\&4):31-7.
7. M Hoque, S Haaq et al. Causes of neonatal admission and deaths at a rural hospital in Kwazulu-Natal South Africa. South Afr J Epidemiol Infect 2011; 26(1):26-9.

8. Anish S, Ann $\mathrm{T}$ et al. Mortality pattern of hospitalized neonates in a tertiary care hospital in Ernaculam. Kerla Med J 2011; Issue 3: 95-102. 